\title{
The Use of an Adjusted Transportation Model, for Optimizing Provision of International Help, in Case of Emergency Situations
}

\author{
Dalibor Kekić1, Miloš Milenković², Aleksandar Čudan ${ }^{1}$ \\ ${ }^{1}$ University of Criminal Investigation and Police Studies, Department of Police \\ sciences, Cara Dušana 196, 11080 Zemun, Serbia; dalibor.kekic@kpu.edu.rs, \\ aleksandar.cudan@kpu.edu.rs \\ ${ }^{2}$ University of Belgrade, Faculty of Organizational Sciences, Jove Ilića 154, \\ 11000 Belgrade, Serbia; mijatov51804@fon.bg.ac.rs
}

\begin{abstract}
This paper focuses on finding a model to optimize the provision for international emergency help, for emergencies caused by natural or man-made disasters. Nowadays, natural and man-made disasters occur more often than before, possibly, due to climate change, industrial activity, urbanization and migration of people. The national institutions for protection and rescue, in many cases, when the emergency situation is declared, cannot often cope and need help. The international organizations have recognized needs to develop mechanisms, which can be used to help affected countries. Examples are European mechanisms for civil protection and numerous guidelines from the United Nations Office for the Coordination of Humanitarian Affairs (OCHA). If the affected country cannot solve the problems and minimize risks for their citizens, material and cultural heritage, Governments send an official request to International Organizations, to obtain different kinds of international help as quickly as possible. However, the problems can appear with costs and other needed resources for providing international help, in terms of country's distance which could provide help or duplication of resources that should be available. Currently, International Organizations do not have the documents, guidelines or software to be used for an emergency, when they have to make optimal decisions, concerning which country will provide help. This can be recognized as a main research gap, which is addressed by this paper. This paper uses operational research, to develop an adjusted transportation model, for optimizing the provision of international help in emergency situations. The main goal of this paper is to find useful solutions for those responsible for emergency management in making decisions for providing help to affected countries. Moreover, we aim to develop a model that will facilitate the appropriate disposition of human and material resources to an affected country in experiencing a disaster. The applied method involves an application of an adjusted transportation model for the case study, based on a real emergency situation during the May floods of 2014, in the Republic of Serbia. Having this in mind, the authors try to provide general results and a model, with a recommendation of how the model can be applied to any emergency situation in the world. The applicability is obvious for the activities of international organizations responsible for emergency management.
\end{abstract}

Keywords: costs; model; disasters; emergency situations; international help 


\section{Introduction}

Natural and man-made disasters generate huge problems for many countries all around the world. The scope and damage of actual emergency situations, caused by natural and man-made disasters, is greater than the past. The number of casualties and victims rise during recent years, commensurate with population densities of affected areas. Also, material damage creates life conditions which need a lot of money and other resources for a recovery phase. But, one of the main characteristics of the actual natural and man-made disasters, is that National borders are not to be officially used during emergency situations. Floods are a good example of a natural disaster, which includes international or regional cooperation, between the affected countries, through which, a river passes. Also, the huge impact of emergency situations toggles countries to think globally, more than locally. If the affected country cannot cope with disasters, it will try to get help from an international source [1].

The international organizations and institutions, such as the European Union and the United Nations, recognize need to unit resources from many member states. The resources are united within the developed mechanisms and frameworks. In 2001, the European Union Civil Protection Mechanism was established, in order to have better cooperation among national civil protection authorities across Europe. Whenever the sheer scale of an emergency overwhelms the response capabilities of a country, the EU Civil Protection Mechanism enables coordinated assistance from its participating states. These include all EU Member States, as well as, Iceland, Macedonia, Montenegro, Norway, Serbia and Turkey. The Mechanism is there to protect EU citizens and extend solidarity outside Europe's borders to people who are affected by disasters and need help. Any country in the world, including, the UN and its Agencies, and International Organizations can request assistance, through the EU Civil Protection Mechanism [2]. On the other side, the United Nations Office for the Coordination of Humanitarian Affairs (OCHA) was established in 1991. OCHA is the part of the United Nations Secretariat responsible for bringing together humanitarian actors to ensure a coherent response to emergencies. OCHA also ensures there is a framework within which, each actor can contribute to the overall response effort [3]. These are the best examples of the organizations and institutions that provide international help, in case of emergency situations declared, due to natural or manmade disasters [4].

However, in practice there are obstacles when non-affected countries want to help to affected country, within developed mechanisms and frameworks. The affected country, needs help as soon as possible. Otherwise, the distance and availability of resources could be potential threats for the organization providing international help. The additional problem occurs when more than one country is affected by natural or man-made disasters. That means that the emergency situation hits the whole region at same time. It is important to make adequate calculations in order to satisfy all of the included parties in chain of providing and obtaining different kinds of help [5]. The adjusted transportation model of operational research 
should be used in practice to reduce costs of logistics and improve organization of providing international help to affected country in order to minimize consequences during natural and man-made disasters. It is important to highlight the different types of natural or man-made disasters. Natural hazards and disasters can be split into three categories: Hydro-meteorological, Geophysical and Biological hazards. Hydro-meteorological disasters are natural processes or phenomena of atmospheric, hydrological or oceanographic nature that may cause loss of life or injury, property damage, social and economic disruption or environmental degradation. These include: floods, droughts, landslides, storms, hurricanes and tidal waves. Geophysical disasters are natural earth processes or phenomena that may cause loss of life or injury, property damage, social and economic disruption or environmental degradation. These include: earthquakes, tsunamis and volcanic eruptions. Biological disasters are processes of organic origin or those conveyed by biological vectors, including exposure to pathogenic micro-organisms, toxins and bioactive substances, which may cause loss of life or injury, property damage, social and economic disruption or environmental degradation. These include: epidemic and insect infestation [6]. On the other side, man-made disasters are caused by human impact and include fires, chemical and technical accidents in industry or traffic. Finally, there are many definitions of emergency situations. For the purpose of this paper, maybe the best definition of emergency situation, that is mostly used in Serbia, is the part of Law, on Emergency Situations mentioning that, "emergency situation is the condition, in which, risks and threats or consequences of catastrophes, extraordinary incidents and other hazards threatening the population, environment and material goods, are of such a volume and intensity, that their occurrence or consequences cannot be prevented or eliminated by regular action on by the authorities and/or services in charge, due to which, it is necessary to deploy special measures, forces and means together with an enhanced work regime, in order to mitigate or eliminate them", [7]. In other words, emergency situations are coming after natural or man-made disasters when there is lack of recourses to provide adequate response. This paper attempts to develop an adjusted general transportation problem, which should be used for any type of emergency situation when affected country does not have enough resources and request international help. The difference of adjusted general transportation problem, when it is used for different types of emergency situations, only appears in terms of the located requested resources. For example, Sweden has resources to help other countries, in case of wild and forest fires, but does not have resources for earthquakes. Conversely, France can help in cases of emergency situations caused by earthquakes. So, the Model, will be in a small extent, changed, according to the different types of emergency situations. Moreover, the Model should be used by someone in the international environment, who is in charge of making optimal decisions concerning recourses to the affected country. Optimal decisions, means decisions that save money and resources and, at the same, time provide all the needs for the affected country.

After the introduction, this paper continues with a theoretical background and methodology, which is based on a case study of the May floods 2014, in the Republic of Serbia. Authors in the first paragraph of the methodology section will 
develop a general model, which after will be used in the formal case study. Finally, results of using a transportation model will be presented and discussed, in order to make final conclusions.

\section{Theoretical Background}

In many areas, where logistic services take an important role, reducing costs of transportation is a constant goal. In order to minimize transportation costs researchers in the area of operational research try to find the model which will propose optimal solutions. Each area has its own characteristics that affect model behavior. However, defining transportation problems and the model, should be useful tools for optimizing the provision of international help, in case of emergency situations.

Humanitarian logistics is defined as "the process of planning, implementing and controlling the efficient, cost effective flow and storage of goods and materials as well as related information from the point of origin to the point of consumption for the purpose of alleviating the suffering of vulnerable people" [8]. One of the main characteristics of humanitarian logistics, is time. When disasters occur, relief needs to happen, as soon as possible. So, the participants of humanitarian logistic chain have to react and take action, very fast. In the meantime, economic criteria plays an important role in the decision process. On the other side, various definitions of logistic can be found in the scientific literature, one says that "Logistics is defined as the planning, organization, and control of all activities in the material flow, from raw material until final consumption and reverse flows of the manufactured product, with the aim of satisfying the customer's and other interest party's needs and wishes i.e., to provide a good customer service, low cost, low tied-up capital and small environmental consequences" [9]. Maybe the better definition, for the purpose of this paper, is that "Logistics is defined as those activities that relate to receiving the right product or service in the right quantity, in the right quality, in the right place, at the right time, delivering to the right customer, and doing this at the right cost (The even R's)" [10]. The latter definition emphasizes the importance of seven things, that have to be in the right place, during the provision of international help to countries affected by natural or man-made disaster. Humanitarian logistics differs from the logistics operations in the commercial supply chains, because of uncertainties in route selection, changing facility capacity, changing demand, safety issues, unused routes and other challenges, like disrupted communication systems, limited availability of resources and the need for efficient and timely delivery [11]. Many unknown factors increase logistic costs, especially those one which refers to transport.

The transportation problem involves finding the lowest-cost plan for distributing stocks of goods or supplies from multiple origins to multiple destinations that demand the goods. The transportation model can be used to determine how to allocate the supplies available from the various factories to the warehouses that 
stock or demand those goods, in such a way that total shipping cost is minimized (i.e., the optimal shipping plan). Usually, analysis of the problem will produce a shipping plan that pertains to a certain period of time (day, week), although once the plan is established, it will generally not change unless one or more of the parameters of the problem (supply, demand, unit shipping cost) changes [12]. The questions are, on which this paper tries to give answer, is it possible to use this kind of model to optimize provision of international help in case of emergency situations?

During the preparation of this paper authors found some guidelines on how to manage humanitarian assistance in disaster situations. For example, the Pan American health organization developed one guideline for effective aid. Humanitarian assistance is beneficial to disaster victims and can play an important role in the development of the country if it is properly coordinated and responds to real needs. Both donors and authorities in disaster-prone countries should keep in mind the several principles for effective humanitarian assistance [13]. This guideline provides a lot of principles that should be used during provision of the international help. But, there is no any tool how to optimize this process in order to reduce cost for sending country or not to duplicate resources in the affected country. Chan with her research team worked on a real-time optimization for disaster response, using a mathematical programming approach. Their mathematical model focuses on providing different kinds of humanitarian aid, but in term of a local response. They proposed a real-time decision support tool, with the use of optimization, to aid post-disaster decision making. They adopted a mathematical programming approach to model the problem, where the decisions are the shipments of commodities from emergency supplies storage facilities to affected communities. They also considered multiple types of commodities and heterogeneous vehicles for transportation. The objective function of their model involves the cost of shortage and a piece-wise linear cost of travel time, to penalize the delays within different time intervals [14]. There are also other models in this area, such as, one developed by Baraka, Yadavalli and Singh. This group of authors worked on a transportation model for an effective disaster relief operation in the SADC region. SADC consists of 15 countries: Angola, Botswana, Democratic Republic of Congo, Lesotho, Madagascar, Malawi, Mauritius, Mozambique, Namibia, Seychelles, South Africa, Swaziland, Tanzania, Zambia, and Zimbabwe [15]. In their paper and with the SADC real-life cases studied, the linear programming model targeted a cost-effective route from origins to supplies, while the spanning tree-based genetic algorithm solved the shortest delivery route, by minimizing both time and cost. The models mentioned in this paragraph try to optimize the humanitarian aid in case of emergency situation. The main targets of optimization are costs and time. But, the existing models do not focus on the provision of global international help in case of large scale disasters when a lot of countries want to help the affected country. This reflects the main aim of this paper, more precisely how to optimize the humanitarian aid and operations in the large international environment using the adjusted transportation model and operational research. 
Namely, some international legislative defines that costs of humanitarian aid providing to affected country will be paid accordingly to agreement between the state which request and state which provide help. Moreover, the practice shows that usually the providing country takes care about transportation and other logistic costs. The main reason is situation of affected country or countries, if the natural or man-made disaster hit the huge territory or the whole region, which probably needs a lot of money for recovery phase, so not need the additional expenses. Besides that, the providing country has the restricted funds for this purpose. There is necessity to find model which will optimize the transport route between the providing and the affected country or countries in case of emergency situations, with the primary goal to minimize the transportation costs. The transportation model should be an option for solving this problem [16].

\section{Methodology}

In this paper, the adjusted transportation model for optimizing provision of international help in case of emergency situations caused by natural is suggested. Many constraints affect the final decision on which country or countries will provide operational and humanitarian aid to one where emergency situation is declared. The humanitarian aid includes human, as well as, material resources. In this paper will be consider deployment and scheduling of rescuers as human resources that help to the domestic search and protection capabilities. One of the most influential constraints is the incompatibility between demand and offer of humanitarian aid. Moreover, a limiting factor should be the budget for providing humanitarian aid and sending rescuers to affected countries. Currently, many countries cope with limited available funds and budget. Otherwise, during natural or man-made disasters principle of solidarity becomes actual. Practice shows that many wants to provide help. The goal is to optimize the number of rescuers which will be deployed to affected countries and at same time to minimize their transportation and other costs related to stay in the affected country. Nevertheless, equipment used by international rescuers should be also limiting factor and constraint. The interoperability between domestic and international rescuers is very important. During the decision-making process it is necessary to take into account that rescuers with the corresponding equipment can be sent, regardless of the costs of sending. Adjusted transportation model will be used for minimization of deployment costs of rescuers. In addition of minimization of transportation costs, model will be developed to optimize international help in terms of satisfying all requests that must be fulfilled when sending international rescue forces. The first request is that all domestic rescue forces should be deployed before international teams arrive in the affected country. The second request is teams will rarely be separated. So, beside the costs, during the optimization aspects, that also should be considered, are constraints that all domestic rescue power has to be used, as well as, that the international teams cannot be separated. 
Also, the catastrophic floods in the territory of the Republic of Serbia, during May 2014, would be used as a case study for creating the model. During the third week of May, exceptionally heavy rains fell on Serbia which was caused by a lowpressure system ('Yvette') that formed over the Adriatic. Record-breaking amounts of rainfall were recorded, more than $200 \mathrm{~mm}$ of rain fell in western Serbia, in a week's time, which is the equivalent of 3 months of rain under normal conditions. Overall the floods affected some 1.6 million people, living in 38 municipalities/cities, mostly located in central and western Serbia. Two cities and 17 municipalities were severely impacted. In reaction to the severe flooding and ensuing landslides, on 15 May, the Government of Serbia declared a state of emergency for the entire territory. At the same time, in order to maximize the effectiveness of the response to the emergency, a request for assistance was sent to the international community, notably to the Governments of the European Union (EU) Member States, EU Candidate Countries in the region, the Russian Federation, the European Commission (EC) and the United Nations (UN). In response, the European Commission immediately activated the EU Civil Protection Mechanism, to call on Member States resources and staff [17].

\subsection{Model Definition}

In order that the affected country satisfied the needs, regarding help from abroad, in the case of an emergency situation, the model has to be properly defined, with all of the actual constraints. First, the affected country will try to solve problem with their own resources. But, when domestic resources are not enough to cope with natural or man-made disasters, the Government of the affected country will send an official request to international organizations, which will immediately consider it and take action. This request will be send to all member countries of the international bodies, of civil protection and humanitarian aid. Then, all countries will answer with possibilities of help. Mostly, they will offer help in terms of human resources with equipment. It is very important that the affected country or countries precisely define what is needed. For example, they need four water rescue teams with boats and engines or divers with all necessary equipment. Finally, the international organizations will answer the affected country as to what they can provide, as international help. Practice shows that many countries want to help on the basis of social and human responsibility.

The model will focus on providing international help, in term of rescuers with appropriate equipment. A general model will be developed and presented, that then can be adopted. 
Table 1

Example of table form of the request for the international help

\begin{tabular}{|c|c|c|c|c|c|}
\hline & $\begin{array}{l}\text { Country that } \\
\text { providing } \\
\text { assistance } 1 \\
\text { (CPA1) }\end{array}$ & $\begin{array}{l}\text { Country that } \\
\text { providing } \\
\text { assistance } 2 \\
\text { (CPA2) }\end{array}$ & $\begin{array}{l}\text { Country that } \\
\text { providing } \\
\text { assistance } 3 \\
\text { (CPA3) }\end{array}$ & $\begin{array}{l}\text { Country that } \\
\text { providing } \\
\text { assistance } 4 \\
(\mathrm{CPA} 4)\end{array}$ & $\begin{array}{c}\text { Number } \\
\text { of } \\
\text { rescuers } \\
- \\
\text { Demand }\end{array}$ \\
\hline $\begin{array}{c}\text { Affected } \\
\text { country - } \\
\text { Area } 1 \text { (A1) }\end{array}$ & c11 & c12 & c13 & c14 & D1 \\
\hline $\begin{array}{c}\text { Affected } \\
\text { country - } \\
\text { Area } 2 \text { (A2) }\end{array}$ & c21 & $\mathrm{c} 22$ & $\mathrm{c} 23$ & c24 & D2 \\
\hline $\begin{array}{c}\text { Affected } \\
\text { country - } \\
\text { Area } 3 \text { (A3) }\end{array}$ & c31 & c32 & c33 & c34 & D3 \\
\hline $\begin{array}{c}\text { Affected } \\
\text { country - } \\
\text { Area } 4 \text { (A4) }\end{array}$ & $\mathrm{c} 41$ & $\mathrm{c} 42$ & $\mathrm{c} 43$ & c44 & D4 \\
\hline $\begin{array}{c}\text { Affected } \\
\text { country - } \\
\text { Area } 5 \\
\text { (NWD) }\end{array}$ & c51 & c52 & c53 & c54 & D5 \\
\hline $\begin{array}{l}\text { Number of } \\
\text { rescuers - } \\
\text { Offer }\end{array}$ & $\mathrm{O} 1$ & $\mathrm{O} 2$ & $\mathrm{O} 3$ & O4 & \\
\hline
\end{tabular}

For the purpose of development, a general model is used in the previous table. Columns of the table represent $m$ countries (in this case, four) which have a possibility to provide help. Countries are marked with CPA1, CPA2, CPA3 and CPA4 whose offers are expressed with number of rescuers and labelled as $\mathrm{O} 1, \mathrm{O} 2$, 03 AND O4. Rows of the table represent $n$ areas of the affected country that need help in terms of rescuers with specialized equipment (points of demand) labelled as A1, A2, A3, A4 and A5. Needs of the affected areas are expressed by known numbers of demand D1, D2, D3, D4 and D5 respectively. Having in mind that one of the goals is to minimize costs of engagement of international rescuers, costs of daily engagement (daily allowances) are taken into account. Daily allowances per one rescuer, from different countries, which should be deployed, marked with $c i j$ from each point CPA $\mathrm{j}=1,2, \ldots, 4$ to any point $\mathrm{A} 1, \mathrm{~A} 2, \mathrm{~A} 3, \mathrm{~A} 4$ and $\mathrm{A} 5, \mathrm{i}=1,2, \ldots$, 5 . The daily allowances of rescuer engagement include different costs, such as, transportation costs, food costs, accommodation costs and costs for using specialized equipment. The transportation costs include the expenses of transportation from domestic to affected country and back, divided on whole days of stay in the affected country, plus daily transportation costs. Also, the number of rescuers which will be deployed from some country to the affected country will be labelled as $\mathrm{x}_{\mathrm{ij}}$. 
We want to minimize the total cost of deploying international help, in terms of rescuer, with specialized equipment and at the same time, to satisfy request from affected country. Moreover, the optimization is also based on constraints that all domestic rescue forces should be used and that international teams cannot be separated. Before defining the model, it is important to define the difference between opened and closed tranportation problems. If the demand and offer are equal, the problem will be closed. Otherwise, as in our case, if the demand and offer are not equal the transportation problem will be open and it can be closed by adding fictitious points. The fictitious points will be domestic rescue powers.

So, regarding the topic of this paper and previously defined minimization goal, the model will be defined as:

$$
F=\sum_{i=1}^{m} \sum_{j=1}^{n} c i j
$$

subject to:

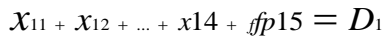

constraint to demand of the first area of the affected country

$x_{21}+x_{22}+\ldots+x_{24}+f f p 25=D_{2}$

constraint to demand of the second area of the affected country

$x_{31}+x_{32}+\ldots+x_{34}+f f p 35=D_{3}$

constraint to demand of the third area of the affected country

$x_{41}+x_{42}+\ldots+x_{44}+f p 45=D_{4}$

constraint to demand of the fourth area of the affected country

$x_{51}+x_{52}+\ldots+x_{54}+f p 55=D_{5}$

constraint to demand of the fifth area of the affected country

$$
x 11 \text { or } x 21 \text { or } X 31 \text { or } x 41 \text { or } x 51=O 1
$$

constraint to offer of the first country including teams cannot be separated

$$
\mathcal{X}_{12} \mathrm{Or}_{22} \mathrm{OrX}_{32} \mathrm{Or} \mathcal{X}_{42} \operatorname{Or}_{52}=\mathrm{O} 2
$$

constraint to offer of the second country including teams cannot be separated

$$
\mathcal{X}_{13} \mathrm{Or}_{23} \mathcal{O r X}_{33} \mathrm{Or} \mathcal{X}_{43} \mathrm{Or} \mathcal{X}_{53}=O 3
$$

constraint to offer of the third country including teams cannot be separated 


$$
\mathcal{X}_{14} \text { Or } \mathcal{X}_{24} \text { orX } X_{34} \text { or } X_{44} \text { or } X_{54}=O 4
$$

constraint to offer of the fourth country including teams cannot be separated

$f p 15+f p 25+f p 35+f p 45+f p 55=F P$

constraint to engagement of domestic rescue powers

$x_{i j} \geq 0$

The objective function (1) is to minimize the total costs of deploying rescuers as one kind of international help to the affected country. The constraints $(2,3,4,5$, 6) shows the potential demand satisfaction of the affected areas of country $i$ $(i=1,2 \ldots, 5)$. These constraints include domestic rescue powers as fictitious points (fp1, fp2...fp5). Constraints $(7,8,9,10)$ show the potential offer of country that express their will and possibility to help the affected country and areas. So, Xij should be equal with $\mathrm{Oj}$ and there is no possibility to have sum of xij which finally will be equal with offer from different countries. Practically, these constraints include fact that international rescue team cannot be separated and all rescuers should be deployed in same affected area. The constraint (11) refers to request that all domestic rescuers should be used. Finally, the natural constraint (12) refers to rule that the number of rescuers cannot be less than zero.

For solving this transportation problem it is important to predefine the costs in euro, per day, of rescuer deploying and working in the affected country. Then, the model will seek to find an optimal solution, that meets the previously defined constraints. That means, the minimized costs of international help and deployment of rescue teams, engagement of all domestic rescue forces and no single separated international team.

\section{Results}

The General Adjusted Transportation Problem, which was developed in the previous chapter, will be adopted through the case study, made from the example of the May 2014 flood, in the Republic of Serbia. During these catastrophic floods, the Republic of Serbia could not cope with the severe consequences and the Serbian Government made the decision to send the official request to international organizations and the European mechanism of civil protection. Also, the help was requested from the nearest countries based on bilateral and multilateral agreements. Immediately, these requests were considered and many countries, through different channels, offered help. It was good news for the Serbian authorities. But, the problem occurred, due to large number of countries that wanted to help. Decision makers had complex tasks in making selection of teams with different specializations and from different parts of the world. 
In this chapter, using the general adjusted transportation model for optimizing provision of the international help, in case of emergency situations, we will show the usefulness of this model, for making optimal decisions. Finally, tables shown in the following part of the paper represent the application of the adjusted transportation problem.

In the beginning of the case study, it should be noted that the countries which have possibilities to provide help, in terms of rescuers with specialized equipment, previously defined the exact costs of deploying the teams. In this case, the biggest influence on total costs will have the distance between the affected Serbian areas and country that will provide help.

The offer and demand for rescuers, as a kind of the international help and the daily allowance, of deploying and rescuing, in euro are shown in Table 2.

Table 2

Offer, demand and daily allowance in case of providing international help in the Republic of Serbia during May floods 2014

\begin{tabular}{|c|c|c|c|c|c|}
\hline & $\begin{array}{l}\text { Country that } \\
\text { providing } \\
\text { assistance } 1 \text { - } \\
\text { Russian } \\
\text { Federation }\end{array}$ & $\begin{array}{l}\text { Country that } \\
\text { providing } \\
\text { assistance } 2 \text { - } \\
\text { Montenegro }\end{array}$ & $\begin{array}{l}\text { Country that } \\
\text { providing } \\
\text { assistance } 3 \text { - } \\
\text { Romania }\end{array}$ & $\begin{array}{l}\text { Country that } \\
\text { providing } \\
\text { assistance } 4 \text { - } \\
\text { Turkey }\end{array}$ & $\begin{array}{l}\text { Number } \\
\text { of } \\
\text { rescuers - } \\
\text { Demand }\end{array}$ \\
\hline $\begin{array}{c}\text { Affected } \\
\text { country } \\
\text { Serbia- } \\
\text { Macva area- } \\
\text { (MA) }\end{array}$ & 80 & 90 & 90 & 90 & 250 \\
\hline $\begin{array}{c}\text { Affected } \\
\text { country } \\
\text { Serbia - } \\
\text { Pcinja area - } \\
\text { (PA) }\end{array}$ & 40 & 60 & 70 & 60 & 220 \\
\hline $\begin{array}{c}\text { Affected } \\
\text { country } \\
\text { Serbia - } \\
\text { Kolubara area } \\
\text { (KA) }\end{array}$ & 70 & 90 & 90 & 70 & 200 \\
\hline $\begin{array}{c}\text { Affected } \\
\text { country } \\
\text { Serbia - } \\
\text { Sumadija area } \\
\text { (SUA) }\end{array}$ & 70 & 100 & 100 & 110 & 250 \\
\hline $\begin{array}{c}\text { Affected } \\
\text { country } \\
\text { Serbia }- \text { Srem } \\
\text { area }(\mathrm{Sa})\end{array}$ & 90 & 120 & 70 & 80 & 200 \\
\hline $\begin{array}{l}\text { Number of } \\
\text { rescuers - } \\
\text { Offer }\end{array}$ & 250 & 150 & 180 & 200 & \\
\hline
\end{tabular}


Before the beginning of the implementation of the transport model, it is necessary to define what the specific fields in the table mean. For example, in the cell which merges the Russian Federation, as a providing country, and Macva area as the affected part of Serbian territory, is written 80 . This means that daily allowance of one Russian rescuer engagement, in the Macva area in Serbia is 80 euro per day. The main goal of the exploited model, is to satisfy the demand for rescuers with predefined offer and to minimize total costs, respecting all constraints. Constraints will be same as in the general model and refer to fact that international teams cannot be separated and that all domestic rescue forces have to be used. Having in mind different types of transportation, Romanian and Montenegrin rescuers used land transport and the Russian and Turkish rescuers used the airport in the city of Nis. This first table in the case study represents the opened transportation problem. The difference is 340 rescuers between demand and offer. More precisely, demand is 340 rescuers higher than the international offer. In next table will be shown the first results of the use of the adjusted transportation model for finding the optimal schedule of providing the international help.

Table 3

The first results of using the transportation model

\begin{tabular}{|c|c|c|c|c|c|c|}
\hline & $\begin{array}{c}\text { Russian } \\
\text { Federation } \\
\text { (number of } \\
\text { offered } \\
\text { rescuers 250) }\end{array}$ & $\begin{array}{c}\text { Montenegro } \\
\text { (number of } \\
\text { offered } \\
\text { rescuers } 150 \text { ) }\end{array}$ & $\begin{array}{l}\text { Romania } \\
\text { (number of } \\
\text { offered } \\
\text { rescuers } \\
180 \text { ) }\end{array}$ & $\begin{array}{l}\text { Turkey } \\
\text { (number } \\
\text { of offered } \\
\text { rescuers } \\
200 \text { ) }\end{array}$ & $\begin{array}{c}\text { F (difference } \\
340 \text { rescuers) } \\
\text { - host nation } \\
\text { capacities }\end{array}$ & $\begin{array}{l}\text { The row } \\
\text { difference }\end{array}$ \\
\hline $\begin{array}{c}\text { Macva } \\
\text { area-(MA) } \\
-250 \\
\text { rescuers } \\
\text { need }\end{array}$ & & & & & 0 & $10,10,0,0$ \\
\hline $\begin{array}{c}\text { Pcinja area } \\
-(\mathrm{PA}) 220 \\
\text { rescuers } \\
\text { need }\end{array}$ & & 150 & & & & 20 \\
\hline $\begin{array}{c}\text { Kolubara } \\
\text { area (KA) } \\
200 \text { rescuers } \\
\text { need }\end{array}$ & & & & & & $0,0,20$ \\
\hline $\begin{array}{c}\text { Sumadija } \\
\text { area (SUA) } \\
250 \text { rescuers } \\
\text { need }\end{array}$ & & & & & & $30,30,0,0$ \\
\hline $\begin{array}{c}\text { Affected } \\
\text { country - } \\
\text { Srem area } \\
\text { (SA) } 200 \\
\text { rescuers } \\
\text { need }\end{array}$ & 30 & & 70 & & 20 & $10,10,10,50$ \\
\hline $\begin{array}{c}\text { The column } \\
\text { difference }\end{array}$ & 30,0 & $30,0,0,10$ & $0,20,20,20$ & $10,10,10$ & & \\
\hline
\end{tabular}


The next step is, the application of transportation model procedure. First, we have to find the two smallest numbers, in each row and each column, which relate to the amount of the daily engagement. When we find that, the next step is to make difference between those numbers. For example, in the first row, which relate to the Macva area - (MA) the two smallest numbers are 80 and 90 . The difference between them is 10 . This is the first number which is written in the first cell of column "the row difference". The procedure will be repeated for all other rows and columns. Than we have to find the biggest number between those that relate to "row and column" difference. In the previous example, it is 30 , but on few positions. In this case, we choose to solve the first column. In the first column, we are looking for the lowest number. This is 40. Finally, we calculate how to satisfy demand and offer it in a cell where the daily engagement is the lowest number, because the model goal is minimization. Pcinja area needed 220 rescuers, and the Russian Federation could provide 250 . So, it is possible to satisfy whole demand and deploy 220 rescuers from Russian Federation to Pcinja district. As a difference, it would leave 30 rescuers from Russian Federation, free. The demand of Pcinja district is fully satisfied. The previously described process will be continued until the demand and offer are not the same. In cases, where the demand was bigger than the offer, we have to add one more column, marked with $\mathrm{F}$, which describe that the difference and will be solved with the host nation capacities and Serbian rescue power. The constraint related to column $\mathrm{F}$ is that all domestic rescue teams have to be engaged. But, the problem is that team cannot be separated, as is in this case with Russian rescuers. So, this result cannot be used as optimal and we have to continue the process.

The next step is to define the level of rank. This is also part of standard solving of transportation problem. A transportation problem's solution has $\mathrm{m}+\mathrm{n}-1$ basic variables, (where ' $m$ ' and ' $n$ ' are the number of rows and columns respectively) which mean that the numbers of occupied cells in the initial basic solution are one less than the number of rows and number of columns. When the number of occupied cells in an initial basic solution is less than $m+n-1$, the solution is called a degenerate solution [18]. The rank is calculated as:

$R=m+n-1$

where $m$ is number of countries which provide help plus domestic capacities, and $\mathrm{n}$ is number of the affected areas.

In this case, the rank is 9. It is necessary, in order to have optimal result, to check if the rank is equal with numbers which are marked in squares and that is popularly called "stones" in the transportation problem. So, we have 8 stones and the rank is 9. They are not equal and we have to continue the process to find the optimal solution. Before next step it is important to include the $\mathcal{E}$. This is an additional tool, without which, we cannot find the optimal result. With the aim to solve degeneracy, the general transportation model needs to allocate an infinitesimally small amount $\mathcal{E}$ to one of the independent cells. More precisely, 


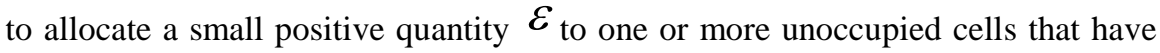
the lowest transportation costs. Also, the value of $\mathcal{E}$ is approximately zero.

Table 4

The second results of using the transportation model T0

\begin{tabular}{|c|c|c|c|c|c|c|}
\hline & $\begin{array}{c}\text { Russian } \\
\text { Federation } \\
\text { (number of } \\
\text { offered } \\
\text { rescuers 250) }\end{array}$ & $\begin{array}{c}\text { Montenegro } \\
\text { (number of } \\
\text { offered rescuers } \\
150 \text { ) }\end{array}$ & $\begin{array}{l}\text { Romania } \\
\text { (number of } \\
\text { offered } \\
\text { rescuers 180) }\end{array}$ & $\begin{array}{c}\begin{array}{c}\text { Turkey } \\
\text { (number of } \\
\text { offered } \\
\text { rescuers 200) }\end{array}\end{array}$ & $\begin{array}{c}F \text { (difference } \\
340 \text { rescuers) - } \\
\text { host nation } \\
\text { capacities }\end{array}$ & $\mathrm{Ui}$ \\
\hline $\begin{array}{l}\text { Pcinja area - } \\
\text { (PA) 220 } \\
\text { rescuers } \\
\text { need }\end{array}$ & 40 & 150 & & 60 & 100 & -30 \\
\hline $\begin{array}{c}\text { Kolubara } \\
\text { area (KA) } \\
200 \text { rescuers } \\
\text { need }\end{array}$ & & & & & & -20 \\
\hline $\begin{array}{c}\text { gSumadija } \\
\text { area (SUA) } \\
250 \text { rescuers } \\
\text { need }\end{array}$ & & & & 200 & & 0 \\
\hline $\begin{array}{l}\text { Affected } \\
\text { country - } \\
\text { Srem area }\end{array}$ & & & 70 & 80 & & 0 \\
\hline $\begin{array}{c}\text { rescuers } \\
\text { need }\end{array}$ & & & & & 20 & \\
\hline $\mathrm{Vj}$ & 70 & 90 & 70 & 90 & & \\
\hline
\end{tabular}

Now we have to assign the potential of the affected areas. It will be Ui where $\mathrm{i}=1,2,3 . .5$. After, the potential of the providing countries is $\mathrm{Vj}$ where $\mathrm{j}=1,2,3 . .5$. Both potentials are calculated in the same way as in the previous table. Ui potential is same as the "row difference" in the previous table. $\mathrm{Vj}$ potential is same as, "column difference" in the previous table. The task is to define the values of base variables:

$$
c i j=U i+V j
$$

and non-base variables

$$
d i j=c i j-U i-V j
$$

In this case, the base variables are the daily allowances for international rescuer engagements in some of the affected areas. The values dij are non-base variables as well as numbers below of diagonal in cells. When this process is finished we have to look are there and dij value less than zero. In this case there is $\mathrm{d}_{54}$ which is -10 . None of the $d i j$ values can be less than zero. So, the result is not optimal and 
we have to continue the transportation problem. Before the next table, we need to connect stones or base variables and to find solutions so all non-base variables, are greater than zero. In next table, we will change the negative value of $\mathrm{d}_{54}$ with $\varepsilon$ and repeat the same process as in previous table.

Table 5

The second results of using the transportation model $\mathrm{T} 1$

\begin{tabular}{|c|c|c|c|c|c|c|}
\hline & $\begin{array}{l}\text { Russian } \\
\text { Federation } \\
\text { (number of } \\
\text { offered } \\
\text { rescuers } \\
250 \text { ) }\end{array}$ & $\begin{array}{c}\text { Montenegro } \\
\text { (number of } \\
\text { offered } \\
\text { rescuers 150) }\end{array}$ & $\begin{array}{l}\text { Romania } \\
\text { (number of } \\
\text { offered } \\
\text { rescuers } \\
180 \text { ) }\end{array}$ & $\begin{array}{l}\text { Turkey } \\
\text { (number of } \\
\text { offered } \\
\text { rescuers } \\
200 \text { ) }\end{array}$ & $\begin{array}{c}\mathrm{F} \\
\text { (difference } \\
340 \\
\text { rescuers) - } \\
\text { host nation } \\
\text { capacities }\end{array}$ & $\mathrm{Ui}$ \\
\hline $\begin{array}{c}\text { Macva } \\
\text { area- } \\
\text { (MA) - } \\
250 \\
\text { rescuers } \\
\text { need }\end{array}$ & 10 & & 20 & & 0 & 70 \\
\hline $\begin{array}{c}\text { Pcinja } \\
\text { area - } \\
\text { (PA) } 220 \\
\text { rescuers } \\
\text { need }\end{array}$ & 4 & & & & 100 & 40 \\
\hline $\begin{array}{c}\text { Kolubara } \\
\text { area }(\mathrm{KA}) \\
200 \\
\text { rescuers } \\
\text { need }\end{array}$ & 220 & 0 & & 7 & & 60 \\
\hline $\begin{array}{c}\text { Sumadija } \\
\text { area } \\
\text { (SUA) } \\
250 \\
\text { rescuers } \\
\text { need }\end{array}$ & 70 & & & & & 70 \\
\hline $\begin{array}{l}\text { Srem area } \\
\text { (SA) } 200\end{array}$ & 30 & & 70 & 80 & 220 & 70 \\
\hline $\mathrm{Vj}$ & 0 & 20 & 180 & 10 & 20 & \\
\hline
\end{tabular}

Now, all non-base variables are positive. So, we have the first optimal solution. But, because one of the non-base variables is equal with zero $\left(d_{22}=0\right)$ we have multiple optimal solution and we will once more repeat process in previous table. The problem with this result is again Russian team's separation on two parts which is contrary to constraints. 
Table 6

The second results of using the transportation model T2

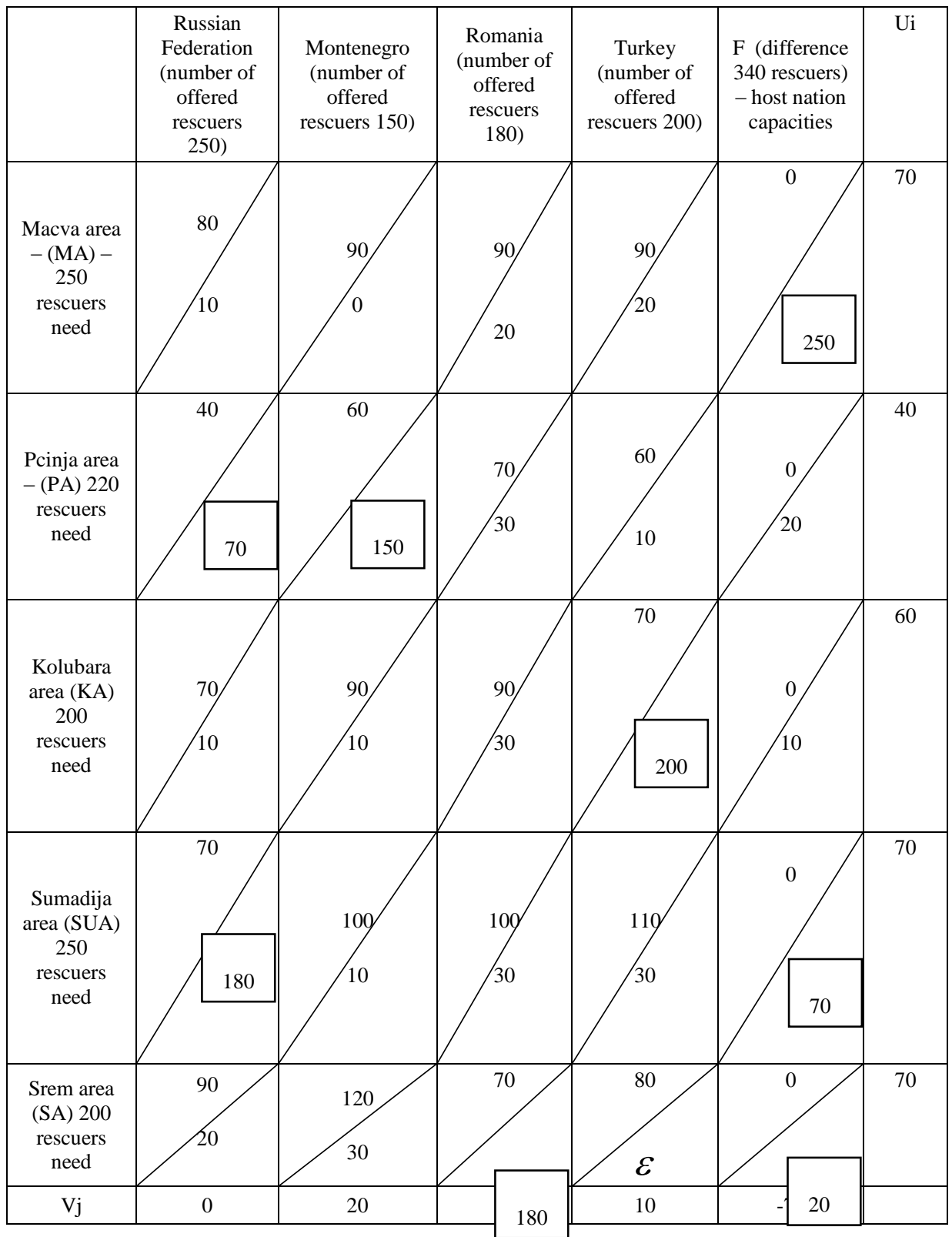

Finally, the last table shows the recommended decision. But, constraints of general model are not satisfied. The Russian team is separated and domestic capacities (column F) are not fully engaged. In next step we have to merge the Russian team. Having in mind all constraints, the Russian team will be connected in the Sumadija area, but not at full capacity. 40 Russian rescuers from Pcinja area 
will be merged with rest of team in the Sumadija area. Demand in the Pcinja area will be satisfied by the Montenegro team, as well as, with domestic rescuers from Pcinja area (20 rescuers), Kolubara area (10 rescuers) and from Sumadija area (40 rescuers). Demand of Sumadija area will be satisfied with 220 Russian rescuers and 30 domestic rescuers. In this way, all constraints are satisfied. Moreover, the Russina Federation will deploy fewer people, 220 rescuers instead of the 250 offered, because all the domestic forces are engaged.

\section{Discussion}

The final result in table 6 and explanation in the last paragraph of previous chapter illustrates the aim of this research, where all demands for rescuers, in the affected districts of the Republic of Serbia are satisfied. Also, we use all offered rescuers, from minimal countries and deployed them with minimal costs, which also was one of the goals. Only the Russian offer was not completely used considering that 220 rescuers will be deployed instead of the 250 offered. According to the adjusted transportation model, goal function and constraints, which are used as part of the case study, we obtained optimal solutions. The Russian Federation, according to the last solution, deployed 220 rescuers to Sumadija district, with the daily costs of 70 euro per day, which is not lowest, but is only 10 euro more than the lowest daily price of engaging Russian rescuers. Moreover, in this case, is the satisfied constraints, that teams cannot be separated and deployed to two different sides. One of the main obstacles, when some countries send their rescuers to help somewhere abroad, is the dividing them on two different sides. Then, Romania deploys all of rescuers to Srem district with the lowest daily price, exactly 70 euro. Montenegro deploys all of rescuers Pcinja district with the lowest daily price -60 euro. Finally, Turkey will deploy all of rescuers to the Kolubara district with daily price which is not lowest, but is only 10 euro more than the lowest daily price of engagement of the Turkish rescuers. Now, by comparing the last solution and the first solution in the table 3 , we can conclude that all of constraints are satisfied. Teams will not be separated and domestic rescue teams are fully engaged.

In the case where many countries want to help an affected country with rescue teams and equipment, using an adjusted transportation problem will facilitate this process. Comparing the first and last option, the costs are the same - 51,000 euros. However, the final solution satisfies all of constraints.

Manual use of a linear programming or transportation problem, without any software, for decision makers in this area, will be too complex. So, the one solution for both obstacles, either for "force-device" calculation model or manual use, is an appropriate software tool. LINDO and LINGO, are examples of software products that can be a useful base for making an appropriate program, or probably sufficient for reducing costs of providing international help in the case of emergency situations [19]. 


\section{Conclusion}

The purpose of this paper is to give a recommendation for using transportation problem solving tools to create a model for providing international help, when natural or man-made disaster occur. In this case, in terms of the rescuers with specialized equipment, with the main goal, to minimize costs. Moreover, the main contribution, as well as, the novelty, is that through this paper, is developed an adjusted transportation model, that should be used by those responsible, to make optimal decisions on provision of international help, in case of emergency situations, with emphasis on deployment of rescue teams with equipment. A special part of this paper belongs to the practical use of a transportation model, which is shown through one case study, belonging to the May floods of 2014, that hit the Republic of Serbia. The one of main finding is that a model is applicable for any kind of emergency situation, caused by natural or man-made disaster. In all cases, is possible to compare requests from an affected country, with offered help. The difference appears only in the numerical indicators for the number of offered rescuers and for the needs of the affected country. Lessons learnt after using the adjusted transportation model, is the need to include all of the practical rules, when the international help is provided. First, all of the domestic teams, in the affected country, have to be engaged. Only in this case, when the national resources are overwhelmed, can the affected country send requests for international help. Secondly, international rescue teams cannot be separated during their work in the affected country. Both of these two constraints are used in the adjusted transportation model, developed in this paper. Maybe the only obstacle now is how to adopt this operational research, as a unique helpful tool, for this topic. In practice it is only possible to recommend, in some general guidelines, and present it at conferences and seminars, to decision makers of the international environment and emergency management community.

Future work will focus on special software, which can be made for this purpose, in connection with the adjusted transportation model. This software should be developed to include existing data, for possible provision of international help, such as, information of currently available teams and equipment. Then, this software, based on predefined constraints, will automatically solve deployment problems and provide optimal results.

\section{Acknowledgement}

Paper is result of research within the project No. 47017 Security and protection of organization and functioning of the educational system in the Republic of Serbia (basic precepts, principles, protocols, procedures and means) realized on the Faculty of Security Studies in Belgrade and financed by Ministry of Education and Science of the Republic of Serbia.

\section{References}

[1] Mladjan, D. and Kekić, D.: Emergency: A contribution toward conceptual determination of security (orig.Vanredna situacija - prilog konceptualnom odredjenju bezbednosti), NBP - Journal of Criminalistics and Law, Vol. 12, No. 3 (2007) pp. 61-83 
[2] The European Commission: EU Civil Protection, Echo Factsheet, 2017

[3] The United Nations: OCHA Brochure, The United Nations Office for the Coordination of Humanitarian Affairs, New York (2016)

[4] Milenković, M. and Kekić, D.: INSARAG, Natural Disasters and Emergencies (orig. Elementarne nepogode i vanredne situacije) Institute of Comparative Law, Academy of Criminalistic and Police Studies, Belgrade, (2015) pp. 46-68

[5] Pálfi, J. and Holcsik, P.: Emergency Situations Management with the Support of Smart Metering, Acta Polytechnica Hungarica, Vol. 13, No. 3 (2016) pp. 195-206

[6] Jan Sørensen; Trond Vedeld; Marit Haug; Natural hazards and disasters Drawing on the international experiences from disaster reduction in developing countries, Norwegian Institute for Urban and Regional Research (NIBR) (2006) pp. 16-17

[7] Law on Emergency Situations, Official Gazette of RS, No. 111/2009, 92/2011 and 93/2012

[8] Safeer, M., S. P. Anbuudayasankar, S. P., Balkumar, K., Ganesh, K.: Analyzing transportation and distribution in emergency humanitarian logistics, $12^{\text {th }}$ Global congress on manufacturing and management, Elsevier Ltd. (2014) pp. 2248-2258

[9] Jonsson,P., Mattsson,S.: Läran om effektiva materialflöden, Lund Studentlitteratur (2005)

[10] Shapiro, D. R., Heskett, L. J.: Logistics Strategy: Cases and Concepts, St.Paul, Minn: West (1985)

[11] Balcik, B. and Beamon, B. M.: Facility location in humanitarian relief, International Journal of Logistics Research and Applications, Vol. 11 (2008) pp. 101-121

[12] Stevenson, W., and Ozgur, C.: Introduction to Management Science with Spreadsheets, New York: McGraw-Hill (2006)

[13] Pan American Health Organization: Humanitarian Assistance in Disaster Situations A Guide for Effective Aid (1999)

[14] Chan, H. H. et al. Real-time optimization for disaster response: A mathematical programming approach, International Journal of Big Data (ISSN 2326-442X) Vol. 2, No. 2 (2015)

[15] Baraka, M., Yadavalli, S., Singh, R.: A transportation model for an effective disaster relief operation in the sadc region, The South African Journal of Industrial Engineering, Vol. 28, No. 2 (2017) DOI:10.7166/28-21311

[16] Afroz, S. and Hasan, B. M.: A Computer Oriented Method for Solving Transportation Problem, Dhaka University Journal of Science, Vol. 63, No. 1 (2015) pp. 1-7 
[17] UNDP, European Commission and World Bank: Serbia floods (2014)

[18] The Institute of Chartered Accountants of India: Advanced Management Accounting, The Transportation Problem, Chapter 11 (2008)

[19] Stevanović, O., Kekić, D., Kónya, V., Milenković, M.: The Use of Linear Programming for Determining Number of Fire - Fighters on Shifts in Case of Special Events, Acta Polytechnica Hungarica, Vol. 13, No. 5 (2016) pp. 155-167 